\title{
Pengaruh Pelatihan Aplikasi Asuhan Keperawatan Spiritual Pasien Covid-19 Terhadap Pengetahuan Perawat Rumah Sakit Rumah Sehat Terpadu Dompet Dhuafa
}

\author{
Murtiningsih $^{1}$ Nedra Wati Zaly ${ }^{2}$ Eddy Afriansyah ${ }^{3}$ \\ ${ }^{1}$ Keperawatan, Sekolah Tinggi Ilmu Kesehatan Jayakarta \\ Email: murtiningsihkadun@gmail.com \\ ${ }^{2}$ Keperawatan, Sekolah Tinggi IImu Kesehatan Jayakarta \\ Email : nedrawatizaly@stikesjayakartapkp.ac.id \\ ${ }^{3}$ Manajemen Informasi Kesehatan, Sekolah Tinggi IImu Kesehatan Jayakarta \\ Email: eddyaf74@gmail.com
}

\begin{abstract}
The purpose of this study was to obtain an overview of the effect of training the application for spiritual nursing care for COVID-19 patients on the knowledge of nurses at the Dompet Dhuafa Integrated Health Hospital. This research method is a quasi-experimental pre post test design. The sampling technique uses total sampling, sample was 22 nurses who nursing care Covid 19 patients at the Dompet Dhuafa Integrated Health Hospital. Collecting data using a google form which contains a questionnaire about spiritual nursing care filled out by respondents before and after the training. Analysis of univariate and bivariate data using paired sample $t$ test. The results showed that prior to being given training in the application of spiritual nursing care, the majority of nurses' knowledge about spiritual nursing care was sufficient (59.1\%). Good knowledge (9.1\%) and poor knowledge (31.8\%). After being given training in the sufficient knowledge category (50\%), there was an increase in the number of nurses in the good knowledge category to (27.3\%) and a decrease in the number of nurses in the less category to (22.7\%). The results of the bivariate paired sample $t$ test analysis showed a significant effect between the pre-test and post-test scores with a significance value (2-tailed) $p=0.026,<0.05$. The recommendation of this study is to continue the next stage for testing the application of spiritual nursing care in web-based and mobile-based Covid 19 patients.
\end{abstract}

Keywords: Web and Mobile Based Applications; Spiritual Nursing Care; Knowledge of Nurses.

Abstrak. Tujuan penelitian ini adalah mendapatkan gambaran tentang pengaruh pelatihan aplikasi asuhan keperawatan spiritual pasien covid 19 terhadap pengetahuan perawat Rumah Sakit Rumah Sehat Terpadu Dompet Dhuafa. Metode penelitian ini quasi eksperimen pre post test design. Teknik pengambilan sampel total sampling dengan jumlah 22 perawat yang merawat pasien Covid 19 di Rumah Sakit Rumah Sehat Terpadu Dompet Dhuafa. Pengumpulan data menggunakan google form yang berisi kuesioner tentang asuhan keperawatan spiritual yang diisi oleh responden sebelum dan setelah pelatihan. Analisa data univariate dan bivariate menggunakan paired sample t test.. Hasil penelitian menunjukkan sebelum diberikan pelatihan aplikasi asuhan keperawatan spiritual menunjukkan mayoritas kategori pengetahuan perawat tentang asuhan keperawatan spiritual adalah cukup (59.1\%). Pengetahuan baik (9.1\%) dan pengetahuan kurang (31.8\%). Setelah diberikan pelatihan kategori pengetahuan cukup (50\%), terjadi peningkatan jumlah perawat yang kategori pengetahuan baik menjadi $(27,3 \%)$ dan penurunan jumlah perawat yang kategori kurang menjadi (22.7\%). Hasil analisa bivariate paired sample t test menunjukkan pengaruh yang signifikan antara nilai pre test dengan post test dengan nilai signifikansi (2-tailed) $p=0,026,<0,05$. Rekomendasi penelitian ini adalah melanjutkan tahapan selanjutnya untuk uji coba aplikasi asuhan keperawatan spiritual pada pasien Covid 19 berbasis web dan mobile.

Kata Kunci : Aplikasi Berbasis Web dan Mobile; Asuhan Keperawatan Spiritual; Pengetahuan Perawat. 


\section{PENDAHULUAN}

Pada tanggal 2 Maret 2020 Presiden Republik Indonesia mengumumkan kasus pertama positif COVID-19 di daerah Depok Jawa Barat. Kasus tersebut setelah ditelusuri terjadi karena adanya kontak dengan orang yang terkena virus Corona. Seorang ibu dan anak tersebut dirawat di Rumah Sakit Penyakit Infeksi Sulianti Saroso, Jakarta Utara. di ruang khusus yang tidak terkontak dengan yang lain. Kemenkes berupaya untuk melakukan tracking kepada semua orang yang telah kontak dengan orang yang positif Virus Corona. Pemerintah menyiapkan rumah sakit yang memiliki ruang isolasi. (Ihsanudin n.d.)

Berdasarkan wawancara terhadap 6 pasien yang positif Covid-19 merasa stress, menyalahkan Tuhan, serta merasa putus asa. Stres juga terjadi pada perawat yang merawat pasien Covid 19. Hasil wawancara terhadap 2 orang perawat yang merawat pasien Covid 19 diantaranya takut jika tertular, tidak bertemu dengan keluarga selama merawat pasien Covid-19.

Asuhan keperawatan secara holistik biopsikososiospiritual perlu dilakukan, akan tetapi aspek spiritual masih belum dilakukan di beberapa Rumah Sakit. Ruang perawatan pasien Covid 19 di Rumah Sakit berbeda dengan Nurse station untuk dokumentasi keperawatan. Perawat tersebut tidak dapat keluar dari ruangan. Komunikasi dari perawat yang dalam ruangan dengan yang di luar ruangan menggunakan intercom sebagai alternatif komunikasi. Tujuan khusus penelitian ini adalah mengidentifikasi penerapan aplikasi ASK pada dokumentasi asuhan keperawatan spiritual pasien Covid 19. Semua perawat yang merawat pasien Covid-19 di Rumah Sakit mempunyai handphone, diharapkan jika dokumentasi menggunakan aplikasi akan mengurangi kontak dengan status pasien yang dilakukan secara manual oleh setiap perawat.

Spiritual dari bahasa Latin berasal dari Kata spiritus yang artinya hembusan atau bernafas, memberikan makna segala sesuatu yang penting bagi hidup manusia. Spiritual Care adalah praktek dan prosedur yang dilakukan oleh perawat terhadap pasien untuk memenuhi kebutuhan spiritual pasien. Pemenuhan kebutuhan spiritual pasien akan menurunkan atau meningkatkan penyembuhan fisik dan mental pasien. Pengetahuan dan keterampilan khusus perlu dimiliki oleh perawat dalam memenuhi kebutuhan spiritual klien ketika dirawat di Rumah Sakit. (Kozier 2008).

1. Asuhan keperawatan spiritual berdasarkan standar diagnosis keperawatan Indonesia

Sebelum pelatihan telah tersususun modul asuhan keperawatan spiritual (Murtiningsih 2021)

a. Pengkajian spiritual (Yodang 2018)

F: Faith atau keyakinan.

Perawat menanyakan keyakinan pasien.

I: Importance dan influence.

Keyakinan yang mempengaruhi perawatan

C: Community.

Perkumpulan yang diikuti dalam komunitas

A: Action

Pengkajian aktifitas sehari-hari pasien yang mengkarakteristikan distres spiritual, mendengarkan berbagai pernyataan penting.

b. Diagnosis Keperawatan

Berikut ini merupakan diagnosa keperawatan terkait kebutuhan spriritual (PPNI 2017)

1.Ansietas (D0080)

2. Berduka ( D0081)

3. Distres Spiritual ( D0082)

4.Keputusasaan (D0088)

5. Risiko Distress Spiritual ( D0100)

2. Aplikasi android asuhan keperawatan spiritual berbasis web dan mobile

Asuhan keperawatan yang telah diberikan oleh perawat perlu didokumentasikan dalam catatan keperawatan. Dokumentasi keperawatan yang dilakukan secara manual pada kertas di status pasien Covid 19 membuat perawat akan kontak dengan perawat lainnya. Apabila pencatatan dilakukan berbasis teknologi informasi akan memberikan keuntungan bagi 
perawat. Diantara keuntungan dokumentasi keperawatan berbasis teknologi informasi ini adalah waktu pendokumentasian yang lebih singkat, keterbacaan data dan kemudahan akses bila dibandingkan dokumentasi dalam format kertas. Pengembangan dokumentasi keperawatan berbasis teknologi informasi tetap harus memperhatikan prinsip kerahasiaan data klien, komprehensif, akurat, tepat waktu, dan jelas mengidentifikasi pemberi perawatan sehingga perlu adanya kebijakan dan pedoman yang jelas bagi tenaga perawat dalam menjalankan sistem ini. Manual book untuk aplikasi asuhan keperawatan spiritual berbasis web dan mobile telah disusun sebagai panduan dalam menggunakan aplikasi asuhan keperawatan spiritual (Murtiningsih; Nedra Wati Zaly; Eddy Afriansyah 2021).

\section{METODE PENELITIAN}

Metode penelitian ini quasi eksperimen pre dan post test. Populasi perawat yang merawat pasien Covid di Rumah Sakit Rumah Sehat Terpadu Dompet Dhuafa, dengan total sampling 22 perawat. Penelitian ini dilakukan melalui dua tahapan, tahap pertama menyiapkan modul asuhan keperawatan spiritual dan membuat aplikasi android asuhan keperawatan spiritual (AKS). Tahap kedua yaitu melakukan pelatihan asuhan keperawatan spiritual dan uji coba aplikasi android AKS berbasis web dan mobile. Modul asuhan keperawatan spiritual telah tersusun. Aplikasi android asuhan keperawatan spiritual telah dibuatkan manual book sebagai panduan dalam mengaplikasikan asuhan keperawatan spiritual pada pasien Covid 19. Sebelum diberikan pelatihan peserta mengisi pre test melalui google form. Pelatihan aplikasi asuhan keperawatan spiritual berbasis web dan mobile diawali dengan materi asuhan keperawatan spiritual, panduan ibadah orang sakit dan penjelasan tentang aplikasi android asuhan keperawatan spiritual. Setelah pelatihan dilakukan post test melalui google form. Analisa data menggunakan paired sample t test.

\section{HASIL PENELITIAN DAN PEMBAHASAN}

\section{a. Hasil Penelitian}

Hasil penelitian dianalisa univariat dan bivariat. Pada analisa univariat mengidentifikasi tingkat pengetahuan perawat sebelum dan setelah pemberin pelatihan. Analisa bivariate untuk menilai pengaruh pelatihan terhadap pengetahuan perawat.

Tabel 1.

Distribusi frekuensi Tingkat pengetahuan perawat sebelum dan setelah pelatihan aplikasi Asuhan Ke=perawatan Spiritual RS RST Dompet Dhuafa ( $N=22)$

\begin{tabular}{lcccc}
\hline \multirow{2}{*}{$\begin{array}{l}\text { Tingkat } \\
\text { Pengetahuan }\end{array}$} & \multicolumn{2}{c}{ Sebelum } & \multicolumn{2}{c}{ Sesudah } \\
\cline { 2 - 5 } & Frekuensi (f) & Persentase (\%) & Frekuensi (f) & Persentase (\%) \\
\hline Baik & 2 & 9.1 & 6 & 27.3 \\
Cukup & 13 & 59.1 & 11 & 50.0 \\
Kurang & 7 & 31.8 & 5 & 22.7 \\
\hline Total & 22 & 100.0 & 22 & 100.0 \\
\hline
\end{tabular}

Hasil penelitian menunjukkan sebelum diberikan pelatihan aplikasi asuhan keperawatan spiritual menunjukkan mayoritas kategori pengetahuan perawat tentang asuhan keperawatan spiritual adalah cukup (59.1\%). Setelah diberikan pelatihan kategori pengetahuan cukup (50\%), terjadi peningkatan jumlah perawat yang kategori pengetahuan baik menjadi $(27,3 \%)$ dan penurunan jumlah perawat yang kategori kurang menjadi (22.7\%). 
Tabel 2.

Hasil uji statistik Paired Sample T-Test Tingkat Pengetahuan Perawat Sebelum dan sesudah pelatihan aplikasi Asuhan Keperawatan Spiritual RS RST Dompet Dhuafa ( $N=22)$

\begin{tabular}{|c|c|c|c|c|c|c|c|}
\hline \multirow[t]{2}{*}{ Test } & \multirow[t]{2}{*}{$\mathrm{n}$} & \multirow{2}{*}{$\begin{array}{c}\text { Statistika } \\
\text { Deskriptif } \\
\text { Mean (Std. D) }\end{array}$} & \multicolumn{2}{|c|}{ IK 95\% } & \multirow[t]{2}{*}{$\mathrm{t}$} & \multirow[t]{2}{*}{ df } & \multirow[t]{2}{*}{ Sig. (2-tailed) } \\
\hline & & & Lower & Upper & & & \\
\hline \multirow{4}{*}{$\begin{array}{l}\text { Pretest } \\
\text { posttest }\end{array}$} & 2 & 62.2727 & & & & \multirow{4}{*}{21} & \multirow{4}{*}{0.026} \\
\hline & 2 & (13.15903) & 12.3306 & -85110 & -2388 & & \\
\hline & 2 & 68.8636 & 3 & & & & \\
\hline & 2 & (16.75679) & & & & & \\
\hline
\end{tabular}

Berdasarkan hasil analisa menunjukkan rata-rata nilai pre test 62.27 dan post test 68.86 . Untuk uji Paire Sample T-Test menunjukkan pengaruh yang signifikan antara nilai pre test dengan post test dengan nilai signifikansi (2-tailed) $p=0,026,<0,05$.

\section{b. Pembahasan}

Berdasarkan hasil penelitian menunjukkan sebelum diberikan pelatihan aplikasi asuhan keperawatan spiritual berbasis web dan mobile didapatkan data mayoritas kategori pengetahuan adalah cukup (59.1\%). Penelitian sebelumnya terkait pengetahuan perawat terhadap pemenuhan kebutuhan psikologis dan spiritual didapatkan hampir setengah responden (41, $4 \%$ ) berpengetahuan cukup (Kiran and Dewi 2017). Hasil penelitian tersebut menunjukkan bahwa yang berpengetahuan baik masih belum banyak, sehingga perlunya diadakan pelatihan asuhan keperawatan spiritual untuk meningkatkan pengetahuan perawat tentang asuhan keperawatan spiritual untuk menjadi lebih baik. Penelitian lainnya terkait pengetahuan perawat tentang asuhan keperawatan spiritual adalah 64 , hal ini tidak dapat mencapai $75 \%$ dari level tertinggi $100 \%$. Hal tersebut diantaranya disebabkan karena minimnya pelatihan asuhan keperawatan spiritual (Niko Sutrisno; Keksi Girindra Swasti; Wastu Adi Mulyono 2019).

Hasil penelitian menunjukkan tingkat pengetahuan setelah dilakukan pelatihan terjadi peningkatan dari sebeleumnya yang memiliki pengetahuan baik sejumlah 2 orang (9.1\%) menjadi 6 orang (27.3\%). Hasil tersebut menunjukkan terjadinya perbedaan pengetahuan antara sebelum dan sesudah diberikan pelatihan. Penelitian lainnya yang meneliti pengaruh pelatihan penerapan asuhan keperawatan spiritual terhadap pengetahuan perawat didapatkan bahwa terjadi perbedaan antara pre dan post test.(Aris Citra Wisuda 2018).

Hasil penelitian menunjukkan terdapat perbedaan rata-rata pengetahuan perawat sebelum dan setelah pelatihan. Sebelum pelatihan rata-rata hasil pre test adalah 62.27 dan setelah pelatihan rata-rata hasil post test adalah 68.86. Perbedaan pengetahuan antara sebelum dan sesudah pelatihan cukup bermakna yang ditunjukkan dengan nilai $p=0,026$. Penelitian tersebut sejalan dengan penelitian sebelumnya yang meneliti tentang pengetahuan asuhan keperawatan spiritual bahwa terdapat perbedaan yang bermakna nilai pre test dan post test dengan nilai signifikansi $0,000<0,05$ (Aris Citra Wisuda 2018). Pelatihan tentang asuhan keperawatan spiritual sebelumnya telah diberikan juga kepada perawat di Rumah Sakit Umum daerah Depok kepada 127 perawat dengan menggunakan modul asuhan keperawatan spiritual. Hasil pre test dan post test menunjukkan terjadi peningkatan pengetahuan perawat tentang asuhan keperawatan spiritual setelah diberikan pelatihan (Murtiningsih; Nedra Wati Zaly; Dyah Fitri Wulandari;Ade Suhendri 2021).

Penelitian ini dilakukan dengan dua tahapan, pada tahap kedua yaitu memberikan pelatihan asuhan keperawatan spiritual dan uji coba asuhan keperawatan spiritual. Analisa pada artikel ini 
menjelaskan tentang pengaruh pelatihan asuhan keperawatan spiritual pasien Covid 19 terhadap pengetahuan perawat. Analisa tentang hasil uji coba aplikasi android AKS akan dijelaskan pada artikel selanjutnya. Analisa tentang uji coba perlu dilakukan untuk menilai penerapannya pada kasus nyata pasien Covid 19 yang dirawat di Rumah Sakit. Penelitian sebelumnya tentang penerapan asuhan keperawatan spiritual telah dilakukan di Rumah Sakit Islam Faisal Makassar(Saharuddin, Amir, and Rosmina 2018). Metode penelitian yang dilakukan adalah metode kualitatif. Hasil tersebut menunjukkan ada 5 tema terkait penerapan asuhan keperawatan spiritual diantaranya proses pengkajian keperawatan spiritual kepada pasien tidak di identifikasi oleh perawat. Tema kedua yaitu diagnosa keperawatan spiritual belum ditegakkan dan didokumentasikan secara maksimal. Tema ketiga yaitu intervensi keperawatan spiritual belum maksimal dan keterbatasan pengetahuan dari perawat. Tema keempat yaitu implementasi keperawatan spiritual sudah dilaksanakan, namun belum menyeluruh baik dari aspek psikomotor maupun dokumentasi. Tema kelima evaluasi keperawatan spiritual tidak dilakukan oleh petugas dan perawat. Berdasarkan hasil temuan tersebut setelah pelatihan peneliti membimbing perawat untuk mengaplikasikan langsung asuhan keperawatan spiritual kepada pasien Covid 19.

\section{KESIMPULAN}

Pada penelitian ini telah tersusun modul asuhan keperawatan spiritual dan aplikasi android asuhan keperawatan spiritual. Pelatihan aplikasi android asuhan keperawatan spiritual berbasis web dan mobile dapat meningkatkan pengetahuan perawat. Berdasarkan analisa statistic didapatkan peningkatan pengetahuan tersebut bermakna. Selanjutnya dilakukan uji coba aplikasi android asuhan keperawatan spiritual langsung kepada pasien Covid 19 yang dirawat di Rumah Sakit. Pada penelitian ini yang dibahas yaitu pengaruh pelatihan terhadap pengetahuan perawat. Rekomendasi selanjutnya dilakukan analisa hasil dari uji coba aplikasi android asuhan keperawatan spiritual berbasis web dan android.

\section{UCAPAN TERIMAKASIH}

Kami mengucapkan terimakasih kepada Kementrian Riset dan Teknologi Pendidikan Tinggi yang telah memberikan dana hibah pada penelitian dosen pemula dan Lembaga Layanan Pendidikan Tinggi (LLDIKTI) Wilayah III. Sekolah Tinggi IImu Kesehatan Jayakarta yang telah mendukung penelitian ini, pihak Rumah Sakit Rumah Sehat Terpadu Dompet Dhuafa sebagai tempat penelitian dan berbagai pihak yang telah membantu terselenggaranya penelitian ini.

\section{DAFTAR PUSTAKA}

Aris Citra Wisuda. 2018. "Pengaruh Pelatihan Penerapan Asuhan Keperawatan Spiritual Dengan Metode Presentasi, Audiovisual Dan Demonstrasi Terhadap Pengetahuan Perawat di RSUD Palembang Bari dan RSUD Dr. Ibnu Sutowo Tahun 2018." Retrieved November 14, 2021 (http://scholar.unand.ac.id/35362/).

Ihsanudin. n.d. "Kasus Pertama Covid Di Jepang." Kompas.Com.

Kiran, Yuke, and Umi Sri Puspita Dewi. 2017. "Pengetahuan Dan Sikap Perawat Dalam Memenuhi Kebutuhan Psikologis Dan Spiritual Klien Terminal." Jurnal Pendidikan Keperawatan Indonesia 3(2):182. doi: 10.17509/jpki.v3i2.9425.

Kozier, at all. 2008. Fundamental of Nursing. New Jersey: Pearson.

Murtiningsih; Nedra Wati Zaly; Dyah Fitri Wulandari;Ade Suhendri. 2021. "Pelatihan Asuhan Keperawatan Spiritual Menggunakan Buku Panduan Persatuan Perawat Nasional Indonesia Melalui Teleconference Bagi Perawat Dan Bidan RSUD Depok." 5(2):33-38. doi: 
https://doi.org/10.36339/je.v5i2.423.

Murtiningsih; Nedra Wati Zaly; Eddy Afriansyah. 2021. "Manual Book Aplikasi Asuhan Keperawatan Spiritual Berbasis Web Dan Mobile." 0-17. Retrieved (https://www.academia.edu/61906532/Manual_Book_Aplikasi_Askep_Spiritual_Berbasis_Web _dan_Mobile).

Murtiningsih. 2021. "Asuhan Keperawatan Spiritual Berdasarkan Standar Diagnosis Keperawatan Indonesia (SDKI), Standar Luaran Keperawatan Indonesia (SLKI), Standar Intervensi Keperawatan Indonesia (SIKI)." Retrieved November 18, 2021 (https://www.academia.edu/s/66e993935d).

Niko Sutrisno; Keksi Girindra Swasti; Wastu Adi Mulyono. 2019. "Pengetahuan, Persepsi Dan Sikap Perawat RSUD Arjawinangun Tentang Asuhan Keperawatan Spiritual." Journal of Bionursing 1(1):11-22. doi: https://doi.org/10.20884/bion.v1i1.18.

PPNI. 2017. Standar Diagnosis Keperawatan Indonesia. 1st ed. Jakarta: DPP PPNI.

Saharuddin, saharuddin, Safrullah Amir, and Rosmina Rosmina. 2018. "Penerapan Model Pelayanan Keperawatan Berbasis Spiritual Ditinjau Dari Aspek Proses Asuhan Keperawatan Spritual Di Rumah Sakit Islam Faisal Makassar." Hospital Majapahit (Jurnal Ilmiah Kesehatan Politeknik Kesehatan Majapahit Mojokerto) 10(1).

Yodang. 2018. Buku Ajar Keperawatan Paliatif. Jakarta: Trans Info Media. 